\title{
UPAYA MENINGKATKAN HASIL BELAJAR EKONOMI MENGGUNAKAN METODE PROBLEM SOLVING PADA PESERTA DIDIK KELAS X DI SMAN 2 KATINGAN HILIR
}

\author{
Oleh \\ Seri Sumiati,* M. Ramli** \\ email: m.ramli@gmail.com
}

\begin{abstract}
This study aims to determine the learning activities of students, and increase the results of economic learning after using the Problem Solving method. This study is a Classroom Action Research (CAR). The subjects of this study were students of class X IPS at SMAN-2 Katingan Hilir consisting of 31 students. Analysis of the data used in this study are qualitative data and quantitative data. Research results (1) Learning activities of Class $\mathrm{X}$ students at SMAN-2 Katingan Hilir after using the Problem Solving Method became good. The first cycle scores an average of 2.45 with the criteria Good Enough, then in Cycle II the average score obtained by students is 3.8 with good criteria. (2) There is an increase in students' economic learning outcomes by using the Problem Solving Method. in the pre-action process when Pre Test obtained an average value of 73 with $42 \%$ classical completeness with criteria not achieved, Cycle I obtained an average value of 82 with classical completeness of $80.64 \%$ with criteria not reached and in post test cycle II obtained an average score -ata 92 with $100 \%$ classical completeness with Reached criteria.
\end{abstract}

(C) Muhammadiyah University Palangkaraya

Keywords: Economic Learning Outcomes, and Problem Solving Methods

\begin{abstract}
ABSTRAK
Penelitian ini bertujuan untuk mengetahui aktivitas Belajar Peserta Didik, dan Peningkatan Hasil Belajar Ekonomi setelah menggunakan metode Problem Solving. Penelitian ini merupakan Penelitian Tindakan Kelas (PTK). Subjek penelitian ini adalah peserta didik kelas X IPS SMAN-2 Katingan Hilir yang terdiri dari 31 peserta didik. Analisis data yang digunakan dalam penelitian ini adalah data kualitatif dan data kuantitatif. Hasil penelitian (1) Aktivitas belajar peserta didik Kelas X di SMAN-2 Katingan Hilir setelah menggunakan Metode Problem Solving menjadi baik. Siklus I skor rata-rata 2,45 dengan kriteria Cukup Baik, kemudian pada Siklus II skor rata-rata yang diperoleh peserta didik adalah 3,8 dengan kriteria baik. (2) Ada peningkatan hasil belajar ekonomi peserta didik dengan menggunakan Metode Problem Solving. pada proses pratindakan saat Pre Test memperoleh nilai rata-rata 73 dengan ketuntasan klasikal $42 \%$ dengan kriteria Tidak Tercapai, Siklus I memperoleh nilai rata-rata 82 dengan ketuntasan klasikal 80,64 \% dengan kriteria Tidak Tercapai dan pada Post Test siklus II memperoleh nilai rata-rata 92 dengan ketuntasan klasikal $100 \%$ dengan kriteria Tercapai.
\end{abstract}

(C) Universitas Muhammadiyah Palangkaraya

Kata Kunci : Hasil Belajar Ekonomi, dan Metode Problem Solving. 


\section{PENDAHULUAN}

Pendidikan berarti bimbingan atau pertolongan yang diberikan secara sengaja terhadap anak didik oleh orang dewasa agar anak didik menjadi dewasa, dalam perkembangan selanjutnya, pendidikan berarti usaha yang dijalankan oleh seseorang atau sekelompok orang untuk mempengaruhi seseorang atau sekelompok orang yang belum dewasa agar menjadi dewasa dan mencapai tingkat hidup yang lebih tinggi dalam arti mental.

Dalam Undang-Undang Nomor 20 Tahun 2003, tentang sistem pendidikan nasional disebutkan bahwa : Pendidikan adalah usaha sadar dan terencana untuk mewujudkan suasana belajar dan proses pembelajaran agar peserta didik secara aktif mengembangkan potensi dirinya untuk memiliki kekuatan spiritual keagamaan, pengendalian diri, kepribadian, kecerdasan, akhlak mulia, serta ketrampilan yang diperlukan dirinya, masyarakat, bangsa dan Negara.

Tujuan pendidikan ialah mengembangkan potensi peserta didik, potensi yang dimaksud adalah potensi yang di bawa peserta didik sejak lahir dan pendidikan juga bertujuan untuk mempersiapkan peserta didik untuk hidup bermasyarakat. Berbicara mengenai tujuan pendidikan dalam hal ini kita mengaitkan dengan tujuan pendidikan di sekolah menengah atas. Mungkin tujuan tidak jauh berbeda dalam pendidikan di sekolah menengah atas juga memiliki tujuan untuk mencerdaskan peserta didik hanya saja di sekolah menengah atas pendidikan yang diberikan berupa pendidikan- pendidikan sebagai bekal mereka untuk memasuki jenjang pendidikan yang lebih tinggi. Faktor yang mempengaruhi tujuan pendidikan di sekolah menengah atas seperti guru, peserta didik dan juga kurikulum. Dalam keseluruhan proses kegiatan belajar mengajar merupakan kegiatan yang paling pokok, hal ini berarti bahwa berhasil tidaknya pencapaian tujuan pendidikan banyak bergantung kepada bagaimana porses belajar mengajar dirancang dan dijalankan secara profesional. Menurut Slameto (2010:2) berpendapat bahwa: Belajar ialah suatu proses usaha yang dilakukan seseorang untuk memperoleh suatu perubahan tingkah laku yang baru secara keseluruhan, sebagai hasil pengalamannya sendiri dalam interaksi dengan lingkungannya.

Dari pendapat yang dikemukakan tersebut di atas, maka dapat ditarik kesimpulan yaitu, belajar merupakan perubahan tingkah laku seseorang melalui suatu proses pengalaman yang dapat memperoleh pengetahuan dalam meningkatkan keterampilan, sikap dan usaha. Sebagai guru harus mampu merancang, memilih, menggunakan dan melakukan program pengalaman belajar dengan tepat untuk menunjang keberhasilan peserta didik dalam mendapatkan pengalaman dan kemampuan belajar untuk mencapai tujuan pembelajaran. Dengan adanya rancangan pembelajaran guru mampu membantu meningkatkan hasil belajar ekonomi dengan menggunakan metode pembelajaran. Metode merupakan suatu cara yang dipergunakan guru untuk mencapai tujuan yang telah ditetapkan. 
Berdasarkan hasil observasi dan wawancara guru Ekonomi menjelaskan bahwa hasil belajar terakhir mata pelajaran ekonomi untuk kelas $\mathrm{X}$ SMAN-2 Katingan Hilir yakni 18 peserta didik dari 31 orang peserta didik dinyatakan tidak tuntas, dari nilai Kriteria Ketuntasan Minimum (KKM) Ekonomi berdasarkan Standar Kompetensi (SK) yakni Memahami Sistem dan Alat Pembayaran serta Kompetensi Dasar (KD) yaitu Memahami penyusunan siklus Sistem dan Alat Pembayaran dengan standar ketuntasan yang ada di SMA Negeri 2 Katingan Hilir yaitu 75. Partisipasi siswa dalam mengikuti kegiatan belajar mengajar di kelas kurang optimal. Kegiatan siswa di dalam kelas selama proses pembelajaran berlangsung hanya mendengarkan penjelasan dari guru dan menjawab pertanyaan guru apabila ditunjuk. Selama KBM siswa cenderung pasif dan hanya terdapat beberapa siswa yang bertanya kepada guru.

Mata pelajaran ekonomi adalah mata pelajaran yang banyak menuntut peserta didik terlibat langsung dalam pembelajaran. Pembelajaran peserta didik harus memiliki keinginan belajar dan motivasi yang berasal dari dalam diri maupun dari luar diri peserta didik tersebut. Dalam pembelajaran ekonomi guru pun diharapkan mampu membangun suasana belajar agar terasa menyenangkan dan guru mampu membawa peserta didik aktif agar peserta didik berminat dan termotivasi dalam proses pembelajaran tersebut, karena guru juga termasuk motivasi eksternal bagi peserta didik.
Metode Problem Solving adalah suatu penyajian materi pelajaran dengan menghadapkan peserta didik kepada persoalan yang harus dipecahkan atau diselesaikan terhadap masalah yang diberikan. Peserta didik akan belajar bagaimana menyelesaikan suatu masalah, menghubungkan antara apa yang mereka pelajari dengan pengetahuan yang mereka miliki sebelumnya.

Menentukan pendekatan dengan Metode Problem Solving merupakan hal yang dapat menentukan pencapaian suatu proses belajar mengajar yang efektif dan efisien. Peserta didik dapat menganalisis dan mendefinisikan masalah mengembangkan hipotesis, mengumpulkan dan menganalisis informasi dan merumuskan kesimpulan.

Penyelesaian masalah merupakan proses dari menerima tantangan dan usaha-usaha untuk menyelesaikannya sampai menemukan penyelesaiannya. menurut Syaiful Bahri Djamarah (2010 : 103) bahwa: Metode Problem Solving (metode pemecahan masalah) bukan hanya sekedar metode mengajar tetapi juga merupakan suatu metode berfikir, sebab dalam problem solving dapat menggunakan metode lain yang dimulai dari mencari data sampai kepada menarik kesimpulan.

Menurut N.Sudirman (2005:146) Metode Problem Solving adalah cara penyajian bahan pelajaran dengan menjadikan masalah sebagai titik tolak pembahasan untuk dianalisis dan disintesis dalam usaha untuk mencari pemecahan atau jawabannya oleh siswa. Sedangkan menurut Gulo (2002:111) menyatakan bahwa Problem Solving 
adalah metode yang mengajarkan penyelesaian masalah dengan memberikan penekanan pada terselesaikannya suatu masalah secara menalar.

Senada dengan pendapat diatas Sanjaya (2009:214) menyatakan pada metode pemecahan masalah, materi pelajaran tidak terbatas pada buku saja tetapi juga bersumber dari peristiwaperistiwa tertentu sesuai dengan kurikulum yang berlaku. Ada beberapa kriteria pemilihan bahan pelajaran untuk metode pemecahan masalah yaitu:

a. Mengandung isu-isu yang mengandung konflik bias dari berita, rekaman video dan lainlain

b. Bersifat familiar dengan siswa

c. Berhubungan dengan kepentingan orang banyak

d. Mendukung tujuan atau kompetensi yang harus dimiliki siswa sesuai kurikulum yang berlaku

e. Sesuai dengan minat siswa sehingga siswa merasa perlu untuk mempelajari.

Dalam pelaksanaan pembelajaran sehari-hari metode pemecahan masalah banyak digunakan guru bersama dengan penggunaan metode lainnya. Dengan metode ini guru tidak memberikan informasi dulu tetapi informasi diperoleh siswa setelah memecahkan masalahnya.

Dari permasalahan yang dikemukakan maka penulis tertarik untuk mengadakan penelitian yang berjudul Upaya Meningkatkan Hasil Belajar Ekonomi Menggunakan Metode
Problem Solving Pada Peserta Didik Kelas X di SMAN 2 Katingan Hilir.

Berdasarkan judul di atas, maka penelitian ini mempunyai tujuan sebagai berikut:

1. Untuk meningkatkan aktivitas peserta didik kelas X SMAN-2 Katingan Hilir dalam pembelajaran ekonomi menggunakan Metode Problem Solving.

2. Untuk meningkatkan hasil belajar ekonomi dengan menggunakan Metode Problem Solving pada peserta didik kelas X SMAN-2 Katingan Hilir.

\section{METODE PENELITIAN}

Penelitian ini menggunakan metode Penelitian Tindakan Kelas (PTK) adalah penelitian tindakan (action research) yang dilakukan dengan tujuan memperbaiki mutu praktik pembelajaran dikelasnya. Tujuan utama PTK adalah memecahkan permasalahan nyata yang terjadi didalam kelas untuk memperbaiki berbagai persoalan nyata dan praktis dalam peningkatan mutu pembelajaran di kelas yang dialami langsung dalam interaksi antara guru dengan siswa yang sedang belajar.

Menerut Kunandar (2010:46), Penelitian tindakan kelas adalah suatu penelitian yang berbasis kepada kelas. Penelitian dapat dilakukan secara mandiri, tetapi alangkah baiknya dilaksanakan secara kolaboratif, baik dengan teman sejawat, kepala sekolah, pengawas, dosen dan pihak yang relevan dengan PTK.

Sedangkan menurut Paizaludin dan Ermalinda (2016:7): Penelitian 
tindakan kelas adalah suatu kegiatan penelitian dengan mencermati sebuah kegiatan belajar yang di berikan tindakan, yang secara sengaja dimunculkan dalam sebuah kelas, yang bertujuan memecahkan masalah atau meningkatkan mutu pelajaran di kelas tersebut. Kemudian menurut Arikunto Suharsimi ( 2002 ) ada beberapa Prinsip Penelitian Tindakan Kelas:

a. Kegiatan nyata dalam situasi rutin

b. Adanya kesadaran diri untuk memperbaikin kinerja

c. Swot sebagai dasar berpijak

d. Upaya empiris dan sistemik

e. Ikuti prinsip SMART dalam perencanaan

Sementara itu dilakukannya PTK di antaranya untuk meningkatkan kualitas pendidikan atau pengajaran yang diselenggarakan oleh pendidik atau peneliti itu sendiri, yang dampaknya diharapkan tidak ada lagi permasalahan yang mengganjal di kelas.

\section{HASIL DAN PEMBAHASAN}

Hasil pengamatan pada penelitian ini memuat pengolahan hasil data dapat diuraikan sebagai berikut :

1. Hasil Observasi Aktivitas Guru Dan Peserta Didik

Hasil observasi oleh dua orang observer terhadap pengolahan pembelajaran pada mata pelajaran Ekonomi pada materi sistem dan alat pembayaran dengan menggunakan Metode Pembelajaran Problem Solving, saat pembelajaran berlangsung dinilai oleh dua orang observer yaitu guru dan teman sejawat.Hasil dengan menggunakan Metode Pembelajaran Problem Solving dikelas X SMAN-2 Katingan Hilir Kasongan menunjukan peningkatan terhadap aktivitas guru pada siklus I dengan memperoleh rata-rata 2,69 dari pengamat 1 (guru), sedangkan dari pengamat 2 (teman sejawat) dengan memperoleh nilai ratarata 2,84 dan aktivitas peserta didik dengan memperoleh ratarata 2,5 dari pengamat 1 (guru), sedangkan dari pengamat 2 (teman sejawat) dengan memperoleh nilai rata-rata 2,4 dan pada siklus II aktivitas guru dengan memperoleh rata-rata 3,53 dari pengamat 1 (guru), sedangkan dari pengamat 2 memperoleh nilai rata-rata 3,38.

2. Nilai Hasil Belajar Peserta Didik Data hasil belajar peserta didik yang diperoleh berdasarkan pada hasil tes dari pra tindakan (pre test) dan post tes siklus I, siklus II dengan mata pelajaran Ekonomi pada peserta didik kelas X SMAN-2 Katingan Hilir Kasongan dengan menggunakan Metode Pembelajaran Problem Solving terhadap materi sistem dan alat pembayaran pada hasil data rekapitulasi hasil belajar peserta dapat disimpulkan bahwa pada hasil tes pra tindakan peserta didik memperoleh rata-rata 73 dengan ketuntasan klasikal 42\%, sedangkan pada post tes saat siklus I hasil belajar peserta didik memperoleh nilai rata-rata 
82 dengan ketuntasan klasikal $80,64 \%$ dan pada saat post test saat siklus II hasil belajar peserta didik memperoleh nilai rata-rata 92 dengan ketuntasan klasikal 100\%, dengan demikian pada saat siklus II memenuhi ketercapaian ketuntasan terhadap hasil belajar peserta didik secara klasikal sehingga peneliti menganggap berhasil. Berdasarkan hasil penelitian di atas, maka upaya pelaksanaan perbaikan hasil belajar peserta didik dengan menggunakan Metode Pembelajaran Problem Solving pada mata pelajaran Ekonomi dengan materi sistem dan alat pembayaran, merupakan salah satu cara untuk meningkatkan aktivitas dan hasil belajar peserta didik.

\section{KESIMPULAN}

Berdasarkan hasil penelitian yang telah dilaksanakan maka dapat disimpulkan bahwa sebagai berikut :

1. Aktivitas belajar peserta didik Kelas X di SMAN-2 Katingan Hilir Kasongan setelah menggunakan Metode Pembelajaran Problem Solving menjadi baik. Siklus I skor ratarata 2,45 dengan kriteria Cukup Baik, kemudian pada Siklus II skor rata-rata yang diperoleh peserta didik adalah 3,8 dengan kriteria Baik.

2. Ada peningkatan hasil belajar ekonomi peserta didik dengan menggunakan Metode Problem Solving pada SMAN-2 Katingan Hilir Kasongan. Hal ini dapat dilihat dari data hasil belajar peserta didik pada proses pratindakan saat Pre Test memperoleh nilai rata-rata 73 dengan ketuntasan klasikal $42 \%$ dengan kriteria Tidak Tercapai, Siklus I memperoleh nilai ratarata 82 dengan ketuntasan klasikal 80,64 \% dengan kriteria Tidak Tercapai dan pada Post Test siklus II memperoleh nilai rata-rata 92 dengan ketuntasan klasikal $100 \%$ dengan kriteria Tercapai.

\section{DAFTAR PUSTAKA}

Depdiknas, (2003). Undang-Undang Nomor 20 Tahun 2003 Tentang Sistem Pendidikan Nasional. Jakarta : Sekretariat Negara.

Gulo, W. (2002). Strategi Belajar Mengajar. Jakarta : PT. Grasindo.

Kunandar, 2010. Langkah Mudah Penelitian Tindakan Kelas Sebagai Pengembangan Profesi Guru Edisi Revisi. Jakarta: PT Raja Grafindo Persada.

Paizaludin dan Ermalinda. (2016). Penelitian Tindakan Kelas. Bandung: Alfabeta.

Sudirman, dkk. (2005). Ilmu Pendidikan. Bandung : Remadja Karya.

Suharsimi Arikunto, dkk, (2002). Prinsip Penelitian Tindakan Kelas, Jakarta: PT Bumi Aksara

Syaiful Bahri Djamara. 2010. Strategi Belajar Mengajar. Jakarta : Rineka Cipta. 